\title{
Perancangan Sistem Kontrol PID untuk Pengendali Sumbu Elevasi Gun pada Turret- gun Kaliber 20 Milimeter
}

\author{
Dimas Kunto, Arif Wahjudi,dan Hendro Nurhadi \\ Jurusan Teknik Mesin, Fakultas Teknologi Industri, Institut Teknologi Sepuluh Nopember (ITS) \\ Jl. Arief Rahman Hakim, Surabaya 60111 Indonesia \\ arif_w@me.its.ac.id
}

\begin{abstract}
Abstrak - Pertahanan negara pada hakikatnya adalah segala upaya pertahanan yang bersifat semesta yang didasarkan pada kesadaran atas hak dan kewajiban warga negara serta keyakinan pada kekuatan sendiri dengan tujuan untuk menjaga dan melindungi kedaulatan negara, keutuhan wilayah NKRI dan keselamatan segenap bangsa. Salah satu alat pendukung pertahanan yaitu senjata laras panjang, Turret-gun. Turret-gun memiliki dua sumbu pergerakan rotasi, yaitu sumbu gerak azimuth dan elevasi. Adapun parameter-parameter yang perlu dipertimbangkan dalam sistem kontrol Turret-gun yaitu dimensi Turret-gun dan ukuran peluru. Adapun langkah-langkah yang dilakukan dalam merancang pengendali PID Turret-gun kaliber $20 \mathrm{~mm}$ ini diawali dengan studi literatur serta studi lapangan mengenai mekanisme dan parameter-parameter yang terdapat pada Turret-gun. Setelah itu dilakukan perancangan transmisi dan sistem kontrol Turret-gun untuk dievaluasi grafik responnya. Hasil evaluasi tersebut selanjutnya akan digunakan sebagai acuan untuk merancang pengendali PID yang sesuai. Selanjutnya pengendali PID yang telah dirancang lalu disimulasikan, sehingga menghasilkan grafik respon yang sesuai dengan kriteria yang dibutuhkan. Hasil yang telah didapatkan dari penelitian ini adalah konstanta PID yang direkomendasikan untuk $K_{P}, K_{I}$, dan $K_{D}$ secara berturut-turut adalah sebesar 23061.024, 37820.07 dan 3515.4 yang menghasilkan transient response dengan nilai overshoot sebesar $19.9 \%$, steady state error sebesar $0 \%$ serta settling time sebesar 0.935 detik. Hasil analisa kestabilan untuk sistem kontrol dengan konstanta PID tersebut menunjukkan bahwa sistem kontrol telah stabil, baik menggunakan metode Root Locus maupun metode RouthHurwitz.
\end{abstract}

Kata Kunci-Elevasi,PID, Root Locus, Turret-gun, ZieglerNichols

\section{PENDAHULUAN}

$\mathrm{P}$ ERTAHANAN negara dapat didukung dengan kecanggihan sarana dan prasarana. Salah satu contoh alat utama sistem pertahanan (Alutsista) yang telah didukung oleh sarana dan prasarana yang canggih Turret-gun. Turret-gun adalah sistem senjata laras panjang yang dapat bergerak untuk mengenai target dengan pergerakan arah dan sudut sesuai dengan target, yang dioperasikan menggunakan remote control. Alasan utama diciptakan turret-gun otomatis adalah untuk melindungi operator turret-gun dari ancaman dan bahaya musuh saat berperang. Besar kecilnya dimensi dari senapan bergantung pada ukuran (kaliber) peluru.

Sistem turret-gun mempunyai 2 sumbu gerak, yaitu sumbu azimuth dan sumbu elevasi. Sumbu azimuth meliputi gerak rotasi turret sebesar $360^{\circ}$ terhadap horizontalnya, sedangkan sumbu elevasi meliputi gerak rotasi laras senjata $70^{\circ}$ terhadap vertikalnya. Dalam penelitian ini yang menjadi fokus utama adalah perancangan kendali pada gerak elevasi laras senjata. Hal yang turut dipertimbangkan dalam perancangan kendali gerak elevasi turret-gun ini salah satunya adalah ukuran peluru, karena ukuran peluru menjadi faktor yang mempengaruhi dimensi dan inersia dari laras senapan. Inersia yang besar membuat sistem sulit bergerak dengan akurat dan presisi, sehingga dibutuhkan pengendali yang sesuai untuk menyelesaikan masalah tersebut.

Salah satu metode yang telah digunakan dalam bidang kontrol adalah pengendali PID. Penelitian sebelumnya oleh [3] membandingkan PID dengan metode yang lain seperti Resolve Motion Control (RAC) dan Acceleration Force Control (AFC). Kemudian [3] juga mengembangkan lagi metodenya dengan menggabungkan RAC dengan AFC yang menggunakan PID dengan perkiraan matriks inersia pada metode AFC menggunakan metode Crude Approximation (CA), namun pengaturan parameter PID masih kurang optimal. Penelitian yang dilakukan oleh [3] adalah perancangan kendali RAC, AFC dan PID pada Turret-gun kaliber 12 milimeter. Sehingga penelitian kali ini ingin menerapkan metode pengendali PID pada sistem gerak elevasi turret-gun kaliber 20 milimeter secara optimal.

\section{II.METODOLOGI PENELITIAN}

\section{A. Studi Literatur dan Lapangan}

Pada tahap ini, studi literatur dilakukan mengenai bentuk Turret-gun yang sudah ada dan sistem kontrol gerak yang menyerupai sistem Turret-gun dari buku referensi, literatur dan jurnal ilmiah yang berkaitan dengan penelitian. Selain itu juga dilakukan studi literatur mengenai teori-teori metode kontrol PID yang akan digunakan serta analisa kestabilan sistem dengan menggunakan software MATLAB.

Studi lapangan dilakukan dengan cara mengumpulkan datadata mengenai turret-gun yang akan dikendalikan, dengan cara mengamati dan mengambil data berupa model 3D dari Turret-gun dan spesifikasi serta dimensinya di PT.PINDAD.

\section{B. Perumusan Masalah}

Pada tahap ini, perumusan masalah dilakukan yang akan dipecahkan pada tugas akhir Perancangan Sistem Kontrol Gerak Turret-gun Sumbu Elevasi dengan Metode Kontrol PID. 


\section{Perancangan Transmisi Gerak Sumbu Elevasi}

Pada tahap ini, perancangan transimisi gerak turret-gun untuk sumbu elevasi dilakukan sesuai dengan kebutuhan yang diinginkan nantinya. Pemilihan spesifikasi dan pembuatan setiap komponen transmisi dengan mempertimbangkan ketersediaan di pasaran agar proses pembuatannya lebih mudah.

\section{D.Perancangan Sistem Kontrol Gerak Sumbu Elevasi}

Tahap ini adalah proses dimana perancangan model matetmatis sistem dan kontrol untuk gerak sumbu elevasi dilakukan. Perancangan kontrol menggunakan metode kontrol PID berdasarkan masukan berupa posisi dan menggunakan data dari motor, transmisi dan sistem turret keseluruhan hingga mendapatkan keluaran awal.

\section{E. Pengujian Kestabilan Sistem pada Gerak Sumbu Elevasi}

Pada tahap ini, pengujian kestabilan dari rancangan kontrol yang telah didapatkan di awal dilakukan dengan menggunakan metode-metode yang telah ditentukan. Apabila sistem tidak stabil sesuai kriteria kestabilan masing-masing metode, maka perlu ditambahkan feedback yang berfungsi untuk menambahkan gain yang dibutuhkan untuk mencapai kestabilan yang diinginkan.

\section{F. Kesimpulan dan Saran}

Pada tahap ini, pengambilan kesimpulan dilakukan dari setiap analisa yang dilakukan dari awal sampai akhir proses perancangan sistem kontrol. Dari hasil kesimpulan yang didapat akan dibuat saran yang akan mendukung untuk perancangan sistem kontrol Turret-gun dengan kaliber yang lebih besar.

\section{HASIL DAN PEMBAHASAN}

\section{A. Model Turret-gun}

Rujukan [4] memodelkan turret-gun secara matematis berdasarkan persamaan dasar untuk gerak dinamis (dynamic equation) sebagai berikut:

$$
D \ddot{\theta}+C \dot{\theta}+G=\tau
$$

Dimana $D$ adalah momen inersia, $C$ adalah efek gaya coriolis dan sentrifugal, sedangkan $G$ pengaruh gravitasi. Gambar 1 menunjukkan penyederhanaan dari bentuk turret-gun.

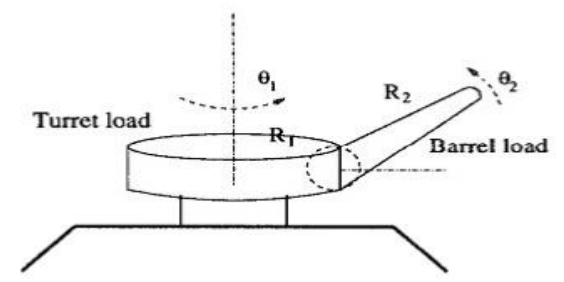

Gambar 1. Sistem Turret-gun [3]

Gambar 1 menunjukkan bahwa sistem turret-gun terdiri dari turret yang memiliki sumbu pergerakan rotasi secara azimuth, dan gun yang memiliki sumbu pergerakan rotasi secara elevasi.
Beberapa persamaan dinamis yang dapat dirumuskan dari Gambar 1 antara lain:

$D_{11}=\frac{1}{2} m_{1} R_{1}^{2}+m_{2} R_{1}^{2}+m_{2} R_{1} R_{2} \cos \left(\theta_{2}\right)+\frac{1}{3} m_{2} R_{2}^{2}\left(\cos \theta_{2}\right)^{2}$

$D_{22}=\frac{1}{3} m_{2} R_{2}^{2}$

$C_{11}=-m_{2} R_{1} R_{2} \sin \left(\theta_{2}\right) \dot{\theta}_{2}$

$C_{12}=-\frac{1}{3} m_{2} R_{2}^{2} \sin \left(2 \theta_{2}\right) \dot{\theta}_{1}$

$C_{21}=-\frac{1}{2}\left(-m_{2} R_{1} R_{2} \sin \left(\theta_{2}\right)-\frac{1}{3} m_{2} R_{2}^{2} \sin \left(2 \theta_{2}\right)\right) \dot{\theta}_{1}$

$G_{21}=\frac{1}{2} m_{2} g R_{2} \cos \theta_{2}$

$C_{22}=G_{11}=0$

Dengan mengacu pada (1), maka dapat kita bentuk menjadi 9) dan (10) yang menyatakan hubungan percepatan sudut $(\ddot{\theta})$ dan torsi $(\tau)$ untuk tiap komponen turret dan gun.

$\ddot{\theta}_{1}=\frac{\tau_{1}-C_{11}}{D_{11}}$

$\ddot{\theta}_{2}=\frac{\tau_{2}-C_{21}-G}{D_{22}}$

\section{B. Model Matematis Sistem kontrol Elevasi Turret Gun}

Sistem turret-gun pada penelitian ini tersusun dari motor DC yang dihubungkan melalui sistem transmisi ke body dari turretgun.

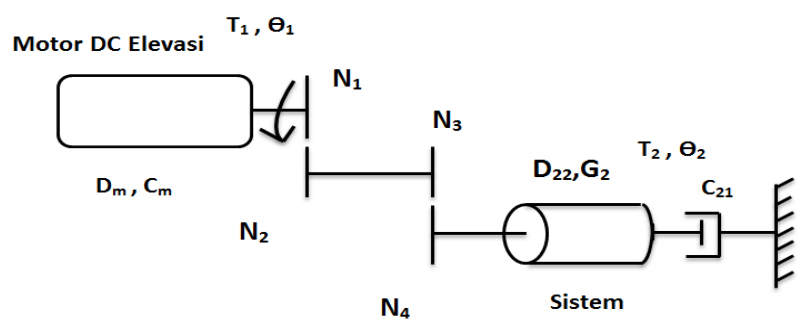

Gambar 2. Free Body Diagram Sistem Elevasi Turret-gun

Masing-masing parameter turret gun sistem elevasi ditentukan sebagai berikut:

- Massa gun, $m_{2}=110 \mathrm{~kg}$

- Panjang gun, $R_{2}=2,76 \mathrm{~m}$

- Transmisi $1, N_{l}=16$

- Transmisi $2, N_{2}=64$

- Transmisi $3, N_{3}=1$

- Transmisi 4, $N_{4}=12,48$

- Momen inersia motor DC, $D_{m}=0,01 \mathrm{Kg} / \mathrm{m}^{2}$

- Voltage constant motor DC, $K_{b}=85 \mathrm{~V} / \mathrm{Krpm}$

- Torque constant motor DC, $K_{t}=0,82 \mathrm{Nm} / \mathrm{A}$

- Armature resistance, $R_{a}=0,61 \mathrm{ohm}$

- Gravitasi, $g=9,8 \mathrm{~m} / \mathrm{s}^{2}$

Gambar 2 menunjukkan sistem tersebut memiliki 2 parameter untuk inersia $(D)$ dan damping $(C)$ dari masingmasing bagian turret-gun dan motor DC, Sehingga dibutuhkan penyederhanaan dari 2 parameter tersebut untuk menghasilkan konstanta ekivalen yang meliputi keseluruhan sistem, yaitu $D_{e q}$ dan $C_{e q}$, yang dirumuskan pada (11) dan (12). Sedangkan pengaruh gravitasi ekivalen $\left(G_{e q}\right)$ besarnya sama dengan pengaruh gravitasi yang dialami gun $\left(G_{2}\right)$ sehingga dapat dirumuskan seperti (13).

$D_{e q}=D_{m}\left(\frac{N 2 N 4}{N 1 N 3}\right)^{2}+D_{22}$ 
$C_{e q}=C_{m}\left(\frac{N 2 N 4}{N 1 N 3}\right)^{2}+C_{21}$

$G_{e q}=G_{2}$

Hubungan antara armature current, $i_{a}(t)$, armature voltage, $e_{a}(t)$, dan back electromotive force, $v_{b}(t)$, dituliskan pada persamaan motor DC sebagai berikut,

$R_{a} I_{a}(t)+L_{a} I_{a}(t)+V_{b}(t)=E_{a}(t)$

Dimana back electromotive force dan armature current adalah,

$V_{b}(t)=K_{b} \dot{\theta_{2}}(t)$

$I_{a}(t)=\frac{1}{K_{t}} T(t)$

$K_{t}$ adalah konstanta torsi dari motor DC (motor torque constant). Untuk mendapatkan transfer function dari motor, maka (15) dan (16) disubstitusikan ke dalam (14), menghasilkan:

$\frac{\left(R_{a}+L_{a}\right) T(t)}{K_{t}}+K_{b} \dot{\theta}_{2}(t)=E_{a}(t)$

Persamaan yang menghubungkan antara torsi dan perubahan sudut dirumuskan sebagaimana pada (10),

$$
T_{2}=D_{e q} \ddot{\theta}_{2}+C_{e q} \dot{\theta}_{1}+G_{e q}
$$

dengan nilai $\dot{\theta}_{1}$ adalah sama dengan nol karena sistem azimuth diasumsikan tidak bergerak (diam), maka

$T_{2}(t)=D_{e q} \ddot{\theta}_{2}(t)+G_{e q}(t)$

Apabila (19) disubstitusikan ke (17),

$\frac{\left(R_{a}+L_{a}\right)\left(D_{e q} \ddot{\theta}_{2}+G_{e q}\right)}{K_{t}}+K_{b} \dot{\theta}_{2}=E_{a}(t)$

Dengan induktansi armature $\left(L_{a}\right)$ diabaikan karena memiliki harga yang sangat kecil untuk motor DC, maka (20) menjadi:

$\frac{R_{a}}{K_{t}} D_{e q} \ddot{\theta_{2}}+K_{b} \dot{\theta_{2}}+\frac{G_{e q}}{K_{t}} R_{a}=E_{a}(t)$

$\frac{R_{a}}{K_{t}} D_{e q} \ddot{\theta}_{2}+K_{b} \dot{\theta}_{2}+\frac{\frac{1}{2} m_{2} g R_{2} \cos \theta_{2}}{K_{t}} R_{a}=E_{a}(t)$

$\ddot{\theta}_{2}=\frac{E_{a} K_{t}-K_{b} \dot{\theta}_{2} K_{t}-\frac{1}{2} m_{2} g R_{2} \cos \theta_{2} R_{a}}{R_{a} D_{e q}}$

Persamaan (22) merupakan persamaaan sistem dengan kondisi nonlinear. Persamaan ini selanjutnya dilinearisasikan dengan metode linearisasi Jacobian. Maka ditentukan,

Misal $\theta_{2}=x_{1}$

$$
\begin{aligned}
& \dot{x}_{1}=x_{2} \\
& \dot{x}_{2}=\frac{E_{a} K_{t}-K_{b} K_{t} x_{2}-\frac{1}{2} m_{2} g R_{2} R_{a} \cos x_{1}}{R_{a} D_{e q}}
\end{aligned}
$$

Persamaan (24) dan (25) merupakan persaman diferensial nonlinear yang akan dilinearisasi di sekitar titik kesetimbangan yang dirumuskan sebagai berikut:

$f_{1}\left(x_{1}, x_{2}\right)=x_{2}=0$
$f_{2}\left(x_{1}, x_{2}\right)=\frac{E_{a} K_{t}-K_{b} K_{t} x_{2}-\frac{1}{2} m_{2} g R_{2} R_{a} \cos x_{1}}{R_{a} D_{e q}}=0$

Pada saat kondisi setimbang, gun diasumsikan dalam keadaan diam atau memiliki kecepatan $\left(x_{2}\right)=0$, Sedangkan untuk $x_{1}=\arccos \frac{2 E_{a} K_{t}}{m_{2} g R_{2} R_{a}}$. Maka, gun akan setimbang di posisi manapun pada batas range antara $\theta_{2} \epsilon\left[-10, \frac{\pi}{3}\right]$, sehingga nilai $\arccos \theta_{2} \epsilon\left[\frac{1}{2}, 1\right]$. Titik kesetimbangan posisi gun dimisalkan adalah $\alpha_{2}$.

$J(\bar{x})=\left(\begin{array}{ll}\frac{\partial f_{1}}{\partial x_{1}} & \frac{\partial f_{1}}{\partial x_{2}} \\ \frac{\partial f_{2}}{\partial x_{1}} & \frac{\partial f_{2}}{\partial x_{2}}\end{array}\right)$

Persamaan (28) adalah persamaan untuk matriks jacobian, dimana $\bar{x}$ adalah titik kesetimbangan dari sistem. Linearisasi di sekitar titik kesetimbangan menjadi sebagai berikut:

$J(\bar{x})=\left(\begin{array}{cc}0 & 1 \\ \frac{-\frac{1}{2} m_{2} g R_{2} R_{a} \sin \alpha_{2}}{R_{a} D_{e q}} & \frac{-K_{b} K_{t}}{R_{a} D_{e q}}\end{array}\right)=A$

Persamaan (29) merupakan matriks A untuk persamaan model state space $\dot{x}=A x+B u$ dan $y=C x+D u$. Matriks $\mathrm{B}, \mathrm{C}$ dan $\mathrm{D}$ ditentukan dengan cara yang sama sehingga didapatkan matriks sebagai berikut:

$B=\left(\begin{array}{c}0 \\ K_{t} \\ R_{a} D_{e q}\end{array}\right)$
$C=\left(\begin{array}{ll}1 & 0\end{array}\right)$
$D=(0)$

Titik keseimbangan ditentukan pada $\theta_{2}=\alpha_{2}=30^{\circ}$, maka apabila masing-masing parameter sistem dimasukkan akan menghasilkan matriks dan model state space sebagai berikut,

$\left[\begin{array}{l}\dot{x}_{1} \\ \dot{x}_{2}\end{array}\right]=\left[\begin{array}{cc}0 & 1 \\ -2,467 & -0,379\end{array}\right]\left[\begin{array}{l}x_{1} \\ x_{2}\end{array}\right]+\left[\begin{array}{c}0 \\ 0,004459\end{array}\right] E_{a}(t)$

$[y]=\left[\begin{array}{ll}1 & 0\end{array}\right]\left[\begin{array}{l}x_{1} \\ x_{2}\end{array}\right]$

Persamaan state space tersebut kemudian dirubah kedalam bentuk transfer function serta diperiksa controlability dan observeability melalui program desain kontrol, didapatkan bahwa sistem telah dapat dikontrol (controllable) dan dapat teramati (observeable) seperti pada Gambar 3 dan respon transient awal sistem seperti pada Gambar 4. 


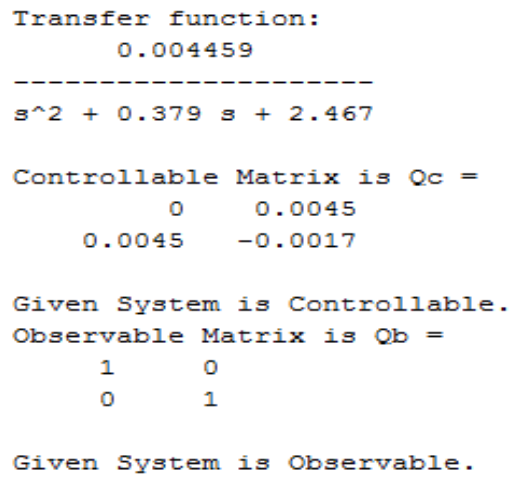

Gambar 3. Hasil Transfer Function

\section{Desain PID dengan Metode Root Locus}

Kriteria desain utama yang ditentukan untuk sistem kontroller antara lain adalah memiliki overshoot $(O S)$ tidak lebih dari $20 \%$, dan settling time $\left(T_{S}\right)$ tidak lebih dari 2 detik serta tidak memiliki steady state error. Blok diagram untuk sistem kontrol turret-gun diilustrasikan pada gambar 4 .

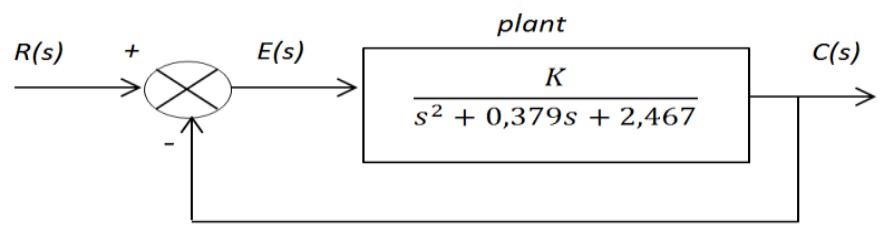

Gambar 4. Uncompensated Feedback Control System untuk Elevasi Turretgun

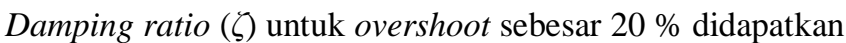
sebagai berikut,

$\zeta=\frac{-\ln \left(\% \frac{O S}{100}\right)}{\sqrt{\pi^{2}+\ln ^{2}\left(\% \frac{O S}{100}\right)}}=\frac{-\ln \left(\% \frac{20}{100}\right)}{\sqrt{\pi^{2}+\ln ^{2}\left(\% \frac{20}{100}\right)}}=0,456$

Sudut yang dibentuk oleh garis overshoot $(\theta)$ dihitung melalui (34), dimana bagian sudut tersebut terlihat pada Gambar 5.

$\theta=180^{0}-\cos ^{-1} \zeta=117,3^{0}$

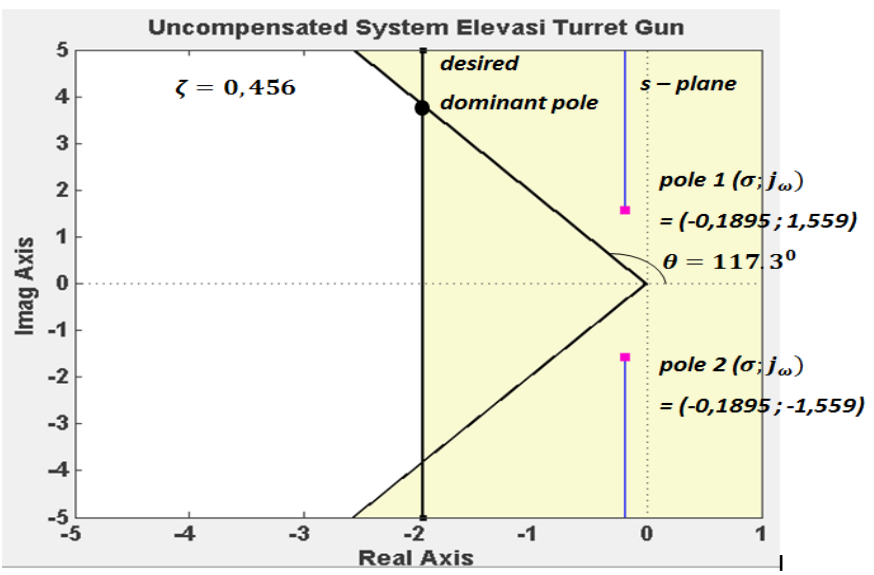

Gambar 5. Root Locus untuk Uncompensated System Elevasi Turret-gun

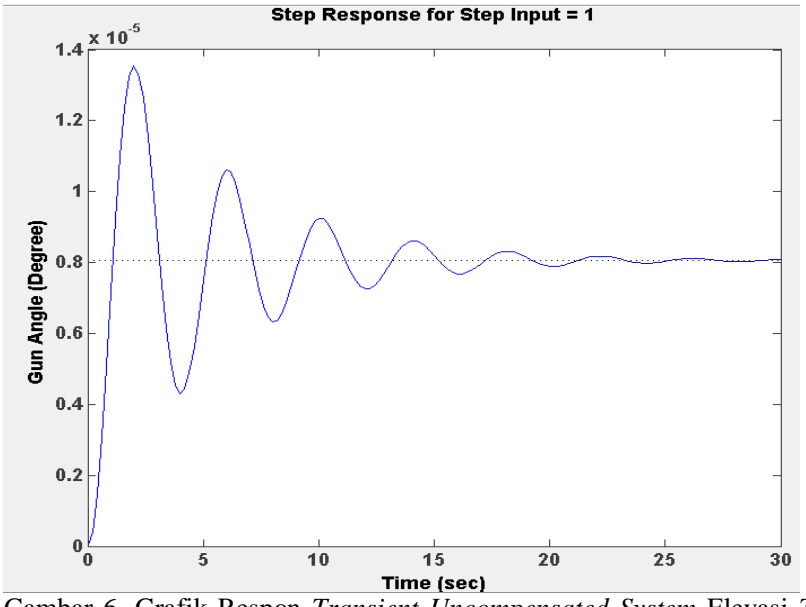

Gambar 6. Grafik Respon Transient Uncompensated System Elevasi Turretgun untuk Step Input $=1$

Gambar 6 menunjukkan grafik respon transient uncompensated system elevasi turret-gun yang memiliki karakteristik sistem jauh dari kriteria desain yang diinginkan, sehingga diperlukan adanya penambahan compensator yang mengacu terhadap desired dominant pole.

Koordinat dari desired dominant pole untuk sumbu imajiner (imaginary axis) dan sumbu real (real axis) didapatkan sebagai berikut:

$\omega_{d}=\omega_{n} \sqrt{1-\zeta^{2}}$

$\omega_{n}=\frac{4}{\zeta T_{S}}=\frac{4}{0,456(2)}=4,386$

$\omega_{d}=4,386 \sqrt{1-0,456^{2}}=3,9035$

$\sigma=-\zeta \omega_{n}=-(0,456)(4,386)=-2$

Besar sudut dan koordinat dari PD compensator (real zero) terhadap titik desired dominant pole didapatkan dengan terlebih dahulu menghitung sudut masing-masing pole terhadap titik desired dominant pole.

$\theta_{1}=180^{\circ}-\tan ^{-1}\left(\frac{2,3445}{1,8105}\right)=127,676^{0}$
$\theta_{2}=180^{\circ}-\tan ^{-1}\left(\frac{5,4625}{1,8105}\right)=108,337^{0}$

Maka sudut compensator zero $\left(\theta_{z}\right)$,

$\theta_{z}-\left(\theta_{1}+\theta_{2}\right)=(2 k+1) 180^{0} ; k=0, \pm 1, \pm 2, \ldots$

$k=0$

$\theta_{z}-\left(127,676^{0}+108,337^{0}\right)=(2(0)+1) 180^{0}$

$\theta_{z}=416,013^{0}-360^{0}=56,013^{0}$

Koordinat untuk compensator zero $\left(-Z_{c}\right)$ dicari dengan menggunakan geometri seperti pada Gambar 7 .

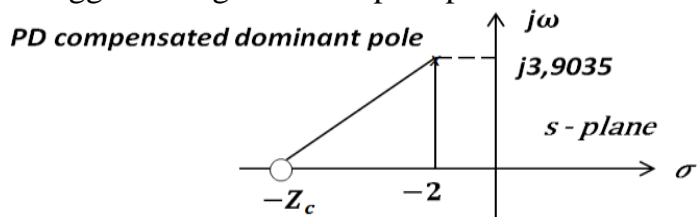

Gambar 7. Geometri Perhitungan dari PD Compensator Zero 
Apabila dimisalkan letak kordinat untuk compensator zero adalah $-Z_{c}$, maka,

$$
\begin{aligned}
\frac{3,9035}{Z_{c}-2} & =\tan 56,013^{0} \\
Z_{c} & =4,6318
\end{aligned}
$$

Maka persamaan compensator untuk PD Controller menjadi,

$$
G_{P D(s)}=(s+4,6318)
$$

dengan Root Locus dan blok diagram serta respon transient untuk PD Compensated system dengan gain yang diperbesar sampai titik PD dominant pole seperti pada Gambar 8, 9 dan 10.

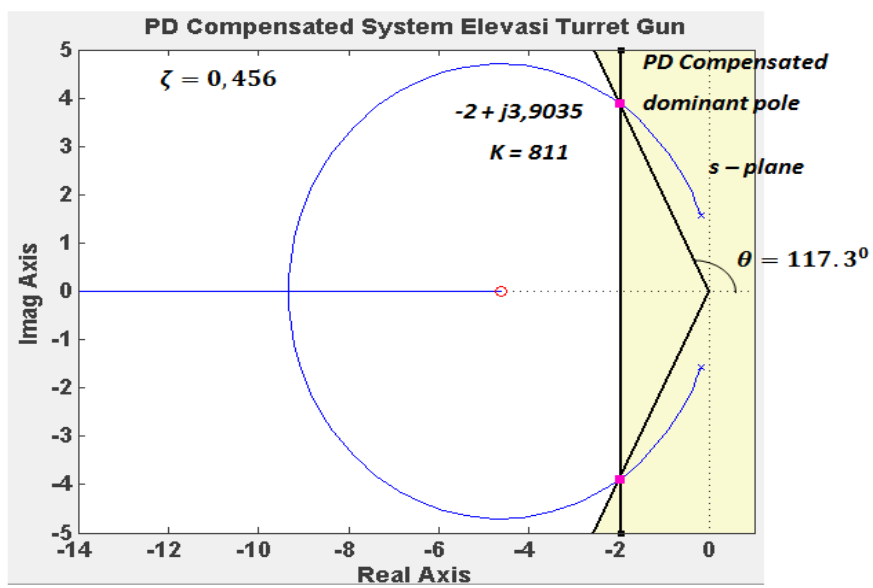

Gambar 8. Root Locus untuk PD Compensated System Elevasi Turret-gun

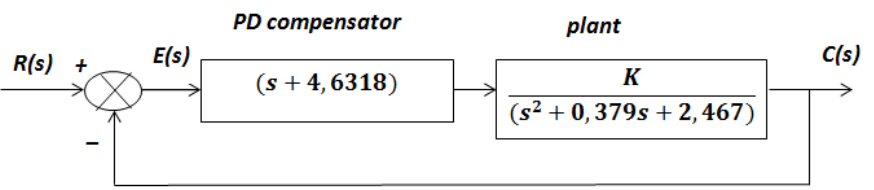

Gambar 9. Blok Diagram untuk PD Compensated System Elevasi Turret-gun

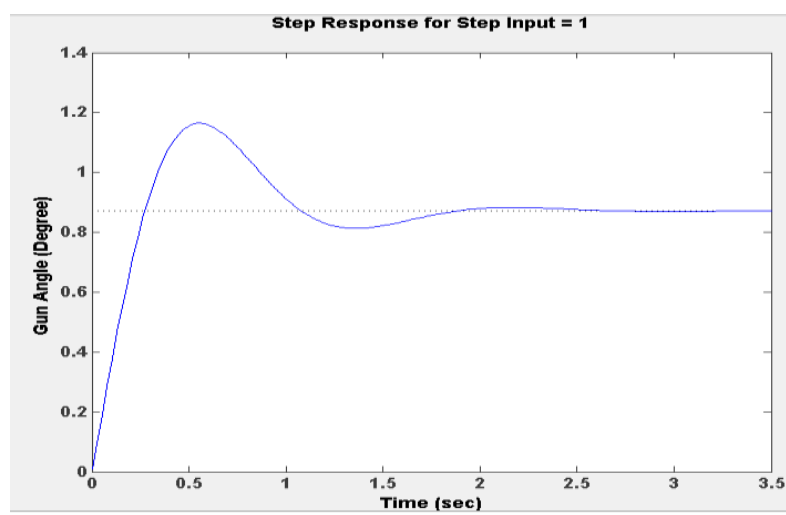

Gambar 10. Grafik Respon Transient PD Compensated System Elevasi Turret-gun untuk Step Input $=1$

Tabel 1.

\begin{tabular}{|c|c|c|}
\hline & Uncompensated & PD Compensated \\
\hline Plant and & $K$ & $K(s+4,6318)$ \\
\hline Compensator & $\overline{s^{2}+0,379 s+2,467}$ & $s^{2}+0,379 s+2,467$ \\
\hline
\end{tabular}

Karakteristik Sistem untuk Uncompensated dan PD Compensated pada Metode Root Locus

\begin{tabular}{ccc}
\hline \hline Dominant & - & $-2 \pm j 3,9035$ \\
Poles & 0,004459 & 811 \\
$K$ & 0,126 & 0,456 \\
$\zeta$ & 1,61 & 4,386 \\
$\omega n$ & 68,2 & 33,6 \\
$\% O S$ & 20,4 & 1,73 \\
$T s$ & 2 & 0,551 \\
$T p$ & - & $-4,6318$ \\
Zero & 99,9 & 12,8 \\
Steady State & & \\
Error $(\%)$ &
\end{tabular}

Tabel 1 menunjukkan bahwa sistem elevasi turret-gun masih memiliki steady state error sebesar 12,8\%. Rujukan [2] menjelaskan kontroller PI yang berfungsi untuk menghilangkan steady state error, diaplikasikan dengan menambahkan pole pada posisi origin serta zero pada sumbu real dengan sembarang posisi yang mendekati posisi origin, sehingga letak posisi pole dan zero baru yang ideal ditentukan dalam persamaan PI compensator sebagai berikut:

$$
G_{P I(s)}=\frac{s+0.1}{s}
$$

Sehingga menghasilkan Root Locus dan blok diagram serta respon transient untuk PID Compensated system dengan gain yang diperbesar sampai titik PID dominant pole seperti pada Gambar 11, 12 dan 13.

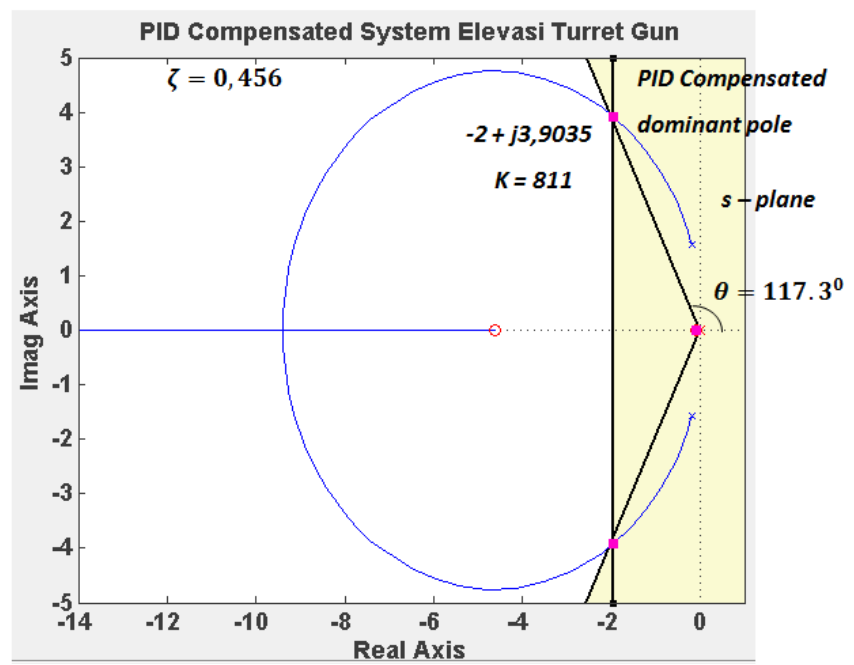

Gambar 11. Root Locus untuk PID Compensated System Elevasi Turret-gun

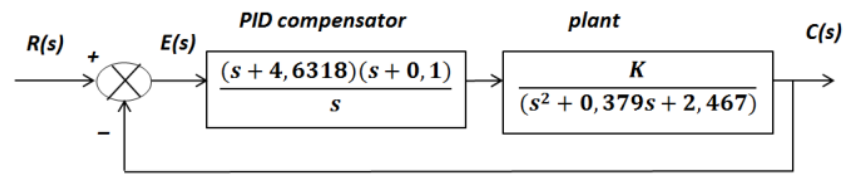

Gambar 12. Blok Diagram PID Compensated System Elevasi Turret-gun 


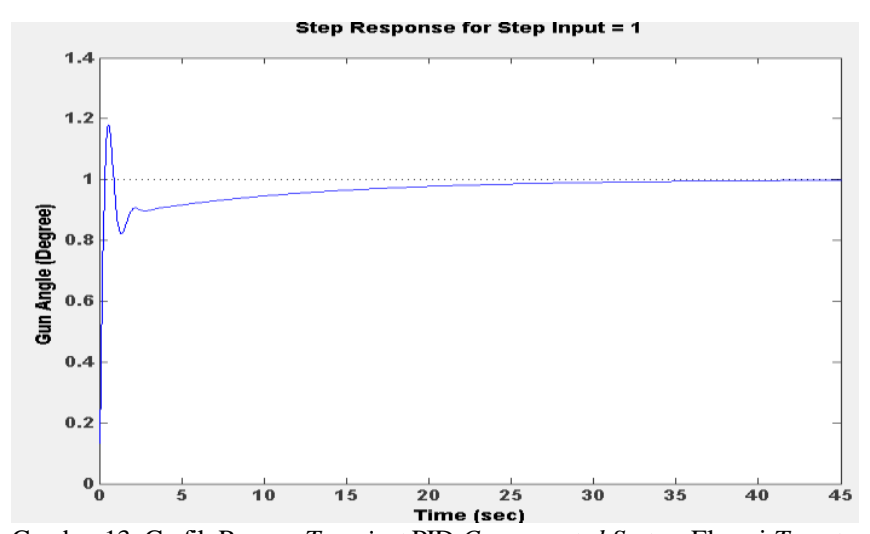

Gambar 13. Grafik Respon Transient PID Compensated System Elevasi Turret-gun untuk Step Input $=1$

Tabel 2

Karakteristik Sistem untuk PD Compensated dan PID Compensated pada Metode Root Locus

\begin{tabular}{ccc}
\hline \hline & PD Compensated & PID Compensated \\
\hline Plant and & $K(s+4,6318)$ & $K(s+4,6318)(s+0,1)$ \\
\cline { 2 - 3 } Compensator & $s^{2}+0,379 s+2,467$ & $s\left(s^{2}+0,379 s+2,467\right)$ \\
Dominant & $-2 \pm j 3,9035$ & $-2 \pm j 3,9035$ \\
Poles & 811 & 811 \\
$K$ & 0,456 & 0,456 \\
$\zeta$ & 4,386 & 4,386 \\
$\omega n$ & 33,6 & 17,9 \\
$\% O S$ & 1,73 & 21,4 \\
$T s$ & 0,551 & 0,564 \\
$T p$ & $-4,6318$ & $-4,6318 ;-0,1$ \\
Zero & 12,8 & 0 \\
Steady State & & \\
Error $(\%)$ & & \\
\hline \hline
\end{tabular}

Adapun konstanta $K_{P}, K_{I}$, dan $K_{D}$ didapatkan sebagai berikut:

$$
\begin{aligned}
& K_{P}=4132,045 \\
& K_{I}=375,638 \\
& K_{D}=811
\end{aligned}
$$

\section{D.Desain PID dengan Metode Ziegler-Nichols}

Desain PID dengan menggunakan metode Ziegler-Nichols untuk step response (metode pertama) pada [1] diawali dengan menentukan delay time $(L)$ seperti pada Gambar 14.

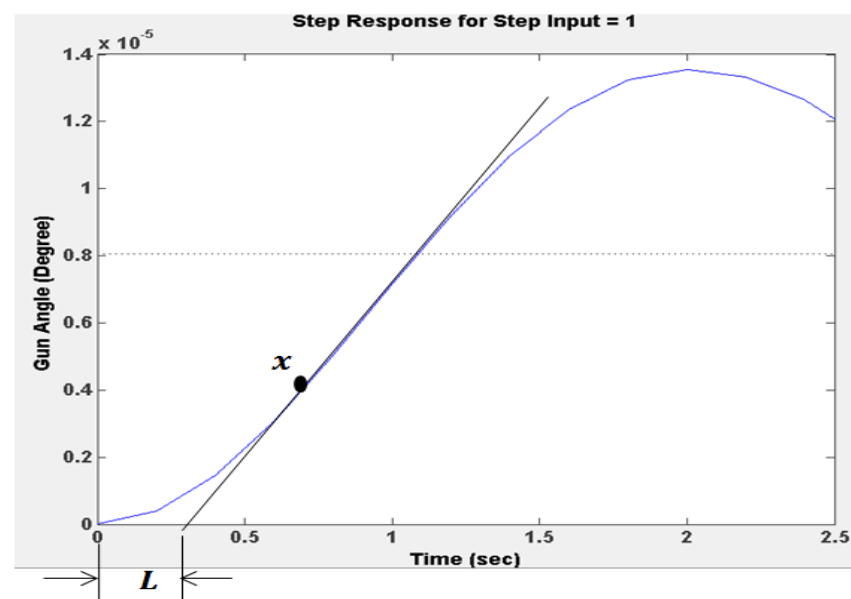

Gambar 14. Penentuan Delay Time $(L)$
Nilai Delay time $(L)$ didapatkan sebesar 0,3048 melalui program desain kontrol, maka letak koordinat 2 real zero compensator berada pada $\sigma_{z}=-\frac{1}{L}=-3,28$. Compensator tersebut akan menghasilkan blok diagram dan Root Locus serta respon transient untuk PID Compensated system dengan gain sebesar 3515,4 seperti pada Gambar 15, 16 dan 17.

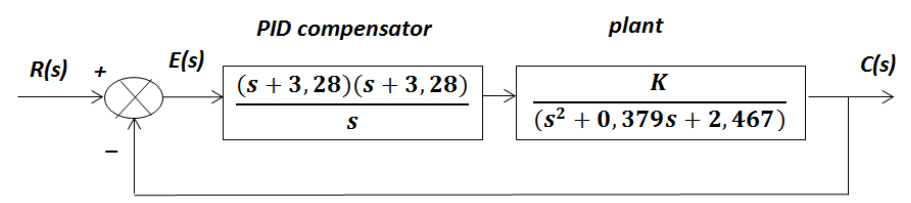

Gambar 15. Blok Diagram PID Compensated System Elevasi Turret-gun

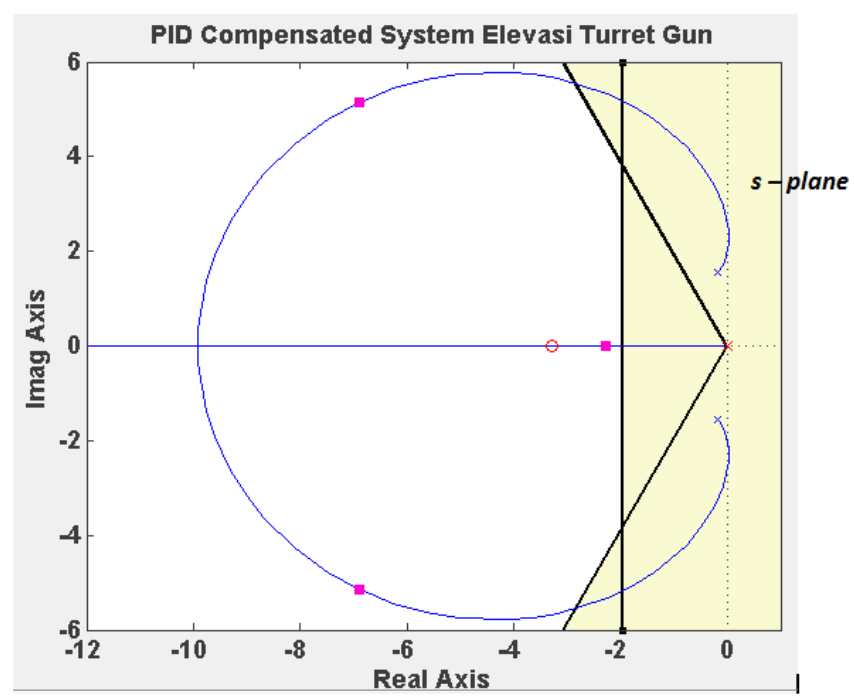

Gambar 16. Root Locus untuk PID Compensated System Elevasi Turret-gun

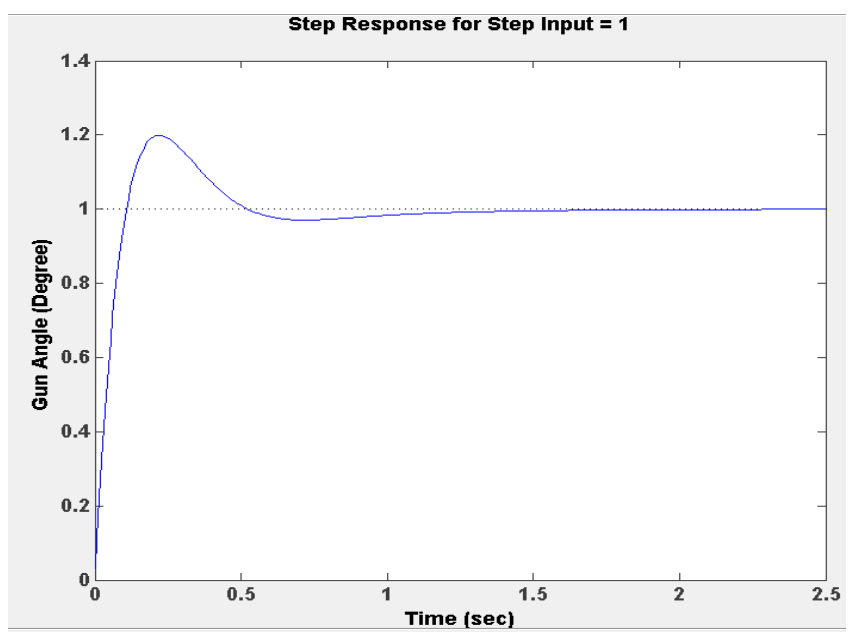

Gambar 17. Grafik Respon Transient PID Compensated System Elevasi Turret-gun untuk Step Input $=1$

Tabel 2

Karakteristik Sistem untuk Uncompensated dan PID Compensated pada Metode

\begin{tabular}{ccc}
\multicolumn{3}{c}{ Ziegler-Nichols } \\
\hline Uncompensated & PID Compensated \\
\hline Plant and & $K$ & $K(s+3,28)(s+3,28)$ \\
\cline { 2 - 3 } \cline { 2 - 3 }$K\left(s^{2}+0,379 s+2,467\right)$ \\
$s^{2}+0,379 s+2,467$ & & 3515,4 \\
$\zeta$ & 0,004459 & 0,801 \\
$\omega n$ & 0,126 & 8,59 \\
$\% O S$ & 1,61 & 19,9 \\
\hline \hline
\end{tabular}




\begin{tabular}{ccc}
\hline \hline$T s$ & 20.4 & 0,935 \\
$T p$ & 2 & 0,221 \\
Zero & - & $-3,28,-3,28$ \\
Steady state error $(\%)$ & 99.9 & 0 \\
\hline \hline
\end{tabular}

Adapun konstanta $K_{P}, K_{I}$, dan $K_{D}$ didapatkan sebagai berikut:

$$
\begin{aligned}
& K_{P}=23061,024 \\
& K_{I}=37820,07 \\
& K_{D}=3515,4
\end{aligned}
$$

\section{E. Analisa Kestabilan}

Metode yang digunakan untuk menganalisa kestabilan sistem elevasi turret-gun untuk metode desain PID Root Locus dan Ziegler-Nichols, antara lain melalui interpretasi Root Locus dan metode Routh-Hurwitz. Interpretasi Root Locus pada gambar 13 dan 17 menunjukkan bahwa sistem turret-gun telah stabil dikarenakan pole sistem tidak ada yang berada pada daerah right-half plane. Sedangkan apabila dianalisa melalui metode Routh-Hurwitz, kedua sistem telah stabil karena menghasilkan routh table dengan koefisien yang tidak memiliki perubahan tanda.

Tabel 3

Routh Table untuk Metode Desain PID dengan Root Locus

\begin{tabular}{ccc}
\hline$s^{3}$ & 1 & 4134,512 \\
$s^{2}$ & 811,379 & 375,638 \\
$s^{1}$ & 4134 & 0 \\
$s^{0}$ & 375,6 & 0 \\
\hline \hline
\end{tabular}

Tabel 4

Routh Table untuk Metode Desain PID dengan Ziegler Nichols

\begin{tabular}{ccc}
\hline \hline$s^{3}$ & 1 & 23063,707 \\
$s^{2}$ & 3515,779 & 37820,07 \\
$s^{1}$ & 23053 & 0 \\
$s^{0}$ & 37820 & 0 \\
\hline \hline
\end{tabular}

\section{KESIMPULAN}

Penelitian ini menunjukkan metode Root Locus yang menghasilkan konstanta $K_{P}, K_{I}$ dan $K_{D}$ berturut-turut sebesar $4132.045,375.638$ dan 811 mempunyai transient response yang belum memenuhi kriteria desain, sedangkan desain PID dengan metode Ziegler-Nichols yang menghasilkan konstanta $K_{P}, K_{I}$ dan $K_{D}$ berturut-turut sebesar 23061.024, 37820.07 dan 3515.4 telah menghasilkan transient response yang telah memenuhi kriteria desain. Apabila ditinjau dari kestabilannya, kedua metode telah menghasilkan sistem kontrol elevasi turret gun yang stabil.

\section{UCAPAN TERIMA KASIH}

Penulis D.K mengucapkan terima kasih kepada PT.PINDAD (Persero) yang telah memfasilitasi penulis dalam melakukan studi lapangan. Semoga penelitian ini dapat memberikan manfaat dan kebaikan bagi banyak pihak.

\section{DAFTAR PUSTAKA}

[1] Ogata, K., (2010), Modern Control Engineering Fifth Edition, Pearson Education, New Jersey.

[2] Norman, S. N., (2011), Control Systems Engineering Sixth Edition, John Wiley and Sons, California State Polytechnic University, Pomona.

[3] Nasyir, M. T. (2014), “Aplikasi Active Force Control pada Turret-gun pada Kendaraan Tempur Darat”, Thesis: Jurusan Teknik Mesin, Institut Teknologi Sepuluh Nopember, Surabaya.

[4] Mushonnifah, S. (2016), "Resolve Acceleration Control (RAC) dan Active Force Control (AFC) pada Sistem Turret-gun Kaliber 20 Milimeter", Thesis: Jurusan Matematika, Institut Teknologi Sepuluh Nopember, Surabaya, belum dipublikasikan. 